\title{
Fermented milk derives bioactive peptides with antihypertensive effects
}

\author{
Amal Bakr Shori ${ }^{* *}$ and Ahmad Salihin Baba ${ }^{2}$ \\ ${ }^{1}$ King Abdulaziz University, Faculty of Science, Department of Biological Sciences, Jeddah 21589, Kingdom of Saudi Arabia \\ ${ }^{2}$ Institute of Biological Sciences, Faculty of Science, University of Malaya, 50603 Kuala Lumpur, Malaysia
}

\begin{abstract}
Functional foods present great promise for future developments in human nutrition. In the fermented dairy products, milk proteins serve as an important source of a range of bioactive peptides encrypted within the sequence of the native proteins and thus be released by proteolysis. From the bioactive peptides detected in dairy products, is inhibitors of angiotensin I-converting enzyme (ACE), which has a central role in the regulation of blood pressure in mammals. Therefore, the objective of this study is to review the possible mechanisms of milk protein proteolysis during fermentation and their relation to function bioactive peptides with antihypertensive effects.
\end{abstract}

\section{Introduction}

Chronic hypertension plays a key role in the development of cardiovascular diseases i.e. arteriosclerosis, stroke and myocardial infraction which lead to renal disease in the end-stage [1]. The high cost and side effects associated with hypertension drugs have encouraged the scientific community to look for alternatives [2]. Other resources of anti- ACE peptides have been identified from animal (chicken muscle, sardine and tuna muscle) and plant proteins (water-soluble extracts of broccoli, mushroom, garlic, buckwheat and wine) as well as in protein hydrolysates of soybean, mung beans, sunflower, rice, corn, wheat, buckwheat and spinach [3]. The dietary approach is preferable because minimal side effects were experienced in comparison to synthetic drugs. The digestion of certain food can results in the formation of active peptides with anti-hypertension activity [4,5]. These bioactive peptides are liberated from the native protein in vivo by digestive proteases or by enzymatic hydrolysis secreted by microorganism during fermentation [6]. The potency of fermented milk derived bioactive peptides against ACE-1 activity has been studied. Hernandez-Ledesma et al. [7] reported that consumption of yogurt is associated with the reduction of blood pressure, made possible due to the liberation of peptides with ACE-I inhibition properties by LAB proteolytic activities [8]. Many peptides with antihypertensive action have been characterized upon fermentation of milk with different microorganisms or by the action of pure proteinases on milk proteins [7,9]. Therefore, the objective of this study is to review the possible mechanisms of milk protein proteolysis during fermentation and their relation to function bioactive peptides with antihypertensive effects.

\section{Proteolysis of milk protein}

Lactic acid bacteria are fastidious microorganisms with regard to nutritional requirements [10]. They have limited biosynthetic ability hence the requirement for an exogenous source of amino acids (such as isoleucine, leucine, valine, histidine and methionine) or peptides for optimum growth [11,12]. Since milk is deficient in such lowmolecular components the growth of the starter bacteria depends on their proteolytic systems to hydrolyze caseins [13]. The amino acids released by the bacteria and accumulated in the milk affect the nutritional potential and biological value of the fermented product. Amino acids may not be directly contributory to the flavour and aroma of fermented milk. However, they act as precursors for a number of reactions that produce carbonyl compounds [14]. The spectrum and level of free amino acids in fermented milk depend on several variables such as type of milk, composition of the starter, method of preparation and storage conditions. Caseins are the main source of amino acids ensuring $98 \%$ of the growth [15]. The contribution of caseins to the provision of essential amino acids depends on the type of proteinase [15]. Proteinase is capable of initiating the degradation of casein to oligopeptides which are transported into the bacteria and afterwards degraded through a complex sequence of intracellular peptidases [15]. The amino acid necessity and production activity in mixed cultures can be modified using selected strains of lactobacilli [16] capable of intracellular splitting of oligopeptides or of attacking peptides and proteins in the nutrient medium by means of the proteolytic enzyme systems synthesized [16].

For example, in the mixed yogurt culture L. bulgaricus has higher proteolytic activity than $S$. thermophilus and thus the free amino acids produced by L. bulgaricus are also used by $S$. thermophilus $[6,17]$. The total amino acid content in yogurt reflects the balance between proteolysis and assimilation by bacteria [17]. The pathway of peptide hydrolysis in yogurt bacteria ensures the release of amino acids respectively and the growth relation between $S$. thermophilus and $L$. bulgaricus $[6,18]$. Proteolysis in fermented milk is mainly related to

Correspondence to: Amal Bakr Shori, King Abdulaziz University, Faculty of Science, Department of Biological Sciences, Jeddah 21589, Kingdom of Saudi Arabia, E-mail: shori_7506@hotmail.com

Key words: milk proteins, proteolysis, hypertension, angiotensin I-converting enzyme

Received: May 10, 2015; Accepted: June 02, 2015; Published: June 05, 2015 
yogurt cultures which explain the high level of proteolysis in fresh biokefir after storage compared to other fermented milk [17]. The pathway of casein catabolism through yogurt organisms can be altered via endopeptidase activity as described for strains of $S$. thermophilus and Lactococcus lactis ssp. lactis, and aminopeptidase as described for L. bulgaricus and Lactobacillus helveticus [17].

\section{Proteolytic agents in fermented milk}

During milk fermentation proteolysis in milk is catalysed by enzymes from:

(1) Coagulant (e.g. chymosin, pepsin, microbial or plant acid proteinases).

(2) Milk (plasmin and perhaps cathepsin D and other somatic cell proteinases).

(3) The starter or non-starter culture.

(4) Secondary cultures (e.g. P. camemberti, P. roqueforti, Propionibacterium sp., B. linens and other coryneforms).

(5) Exogenous proteinases or peptidases, or both, which are produced during milk fermentation.

The initial hydrolysis of caseins during milk fermentation is occurred by the coagulant and to a minor range by plasmin which caused the creation of large- (water-insoluble) and intermediate-sized (water-soluble) peptides that are released afterward by the coagulant and enzymes from the starter and non-starter microflora of the milk $[11,12]$. The extracellular cell envelope-associated proteinase of Lactococccus (lactocepin, endopeptidase lactocepin) contributes to the formation of small peptides in milk. This occurred possibly by the hydrolysis of larger peptides produced from as1-casein by chymosin or from $\beta$-casein by plasmin $[19,20]$. The peptidases (which are intracellular) released from lysed cells are responsible for the breakdown of short peptides and the liberation of free amino acids $[17,21]$. The resulted products of proteolysis are free amino acids. Thus, their quantity in milk at any phase of fermentation is the net result of the released amino acids from casein, their degradation to catabolic products and maybe some synthesis by the milk microflora [14]. Therefore proteolysis can vary significantly between variety e.g. coagulants which are completely denatured by fermentation temperature used in milk manufacture.

\section{Functionality of bioactive peptides}

The physiologically active components of proteins in the food are being widely recognized. The physiological action of natural proteins present in raw food materials can exert directly or indirectly upon enzymatic hydrolysis in vitro or in vivo. Dietary proteins deliver a good source of naturally active peptides [22]. These peptides are inactive within the structure of the native protein but can be liberated via hydrolysis with digestive enzymes and/or proteolytic activity of microorganisms or plants. It is currently well-known that biologically active peptides are generating from food proteins during fermentation with LAB and gastrointestinal digestion. The production and properties of bioactive peptides have been reported in several studies [12,21,23,24].

Bioactive peptides have been defined as particular protein fragments that have physiological effect on human body and may eventually influence health [25]. Oral administration of bioactive peptides has significant effect on functions of human body systems such as cardiovascular, digestive, immune and nervous systems depending on the amino acid sequence of these peptides. Therefore, the potential of different dietary peptide sequences to stimulate human health by lowering the risk of chronic diseases or improving immune system has been widely studied [12,21,24]. Several known peptide sequences showed therapeutic properties such as anti-microbial, antioxidative, anti-thrombotic, anti-hypertensive and immunomodulatory activities [23]. These activities are relied on the amino acid composition and sequence of these peptides. The length of bioactive peptides is generally 2-20 amino acid residues and some peptides can exert multifunctional properties [26]. Nowadays, the most important source of bioactive peptides is milk proteins because these peptides have been identified and isolated from milk protein hydrolysates and fermented dairy products $[12,15,21,24]$.

\section{Hypertension}

Hypertension is the most common cardiovascular diseases. It is a universal problem of epidemic proportions, that affects $10 \%-20 \%$ in the adult population and $40 \%-50 \%$ in people aged 50 or older [27]. It is one of the serious chronic health problems associated with several diseases such as arteriosclerosis, stroke, myocardial infarction and end-stage renal disease. So, the role of the rennin-angiotensin system (RAS) in cardiovascular physiology is well studied and exploited pharmacologically.

The angiotensin converting enzyme (ACE), a component of RAS catalyzes the formation of the strong pressor agent angiotensin II from angiotensin I help to control high blood pressure [28,29]. ACE inhibitors are competitive substrates for ACE. The primary structural control this inhibitory response is the $\mathrm{C}$-terminal tripeptides sequence. These peptides may interact with subsites $s_{1}, s_{1}$, and $s_{2}$, at the active site of ACE. Substrates and inhibitors containing hydrophobic amino acid residues in the three $\mathrm{C}$-terminal positions are preferable for ACE [30]. For example, aliphatic, basic and aromatic residues are binding in the penultimate positions, whereas aromatic, proline and aliphatic residues are binding in the ultimate positions. The positive charge of arginine or the $\varepsilon$-amino group of lysine at the $\mathrm{C}$-terminus has been shown to play role of several ACE-peptides [31]. Several ACE inhibitors such as captopril, enalapril, lisinopril and temocapril are known for the management of hypertension. All of these drugs produced side effects thus, justifying the search for natural ACE inhibitors for safe and economical use [29,32].

\section{Milk-protein-derived peptides with antihypertensive effects}

Recently the ingesting of fermented milk has increased because of the fact that this dairy product fulfills several of human nutritional requirements. It is a ready to eat food moderately low in fat and fulfil the requirements of human nutrition. Recently, the use of functional foods has been increased because of increasing consciousness among people of the linkage between food and health [23]. Fermented milk considered being functional food particularly when it contains probiotic bacteria. It is also offer additional benefits related to the bioactive peptides that are generated during manufacturing and storage. Presently, an excessive attention has been focused on bioactive-peptides that can reduce the blood pressure in hypertensive people [23]

The action of these peptides is relying on the inhibition of angiotensin-I converting enzyme (ACE, E.C. 3.4.15.1). However, the activity of these peptides could include various complex mechanisms that may increase the therapeutic properties of fermented milk followed by further benefits for consumer health $[8,33,34]$. ACE is an enzyme that has an important role in the rennin-angiotensin system 
by controls the arterial blood pressure and the balance of water and salt in the body. An elevation in blood pressure is occurred when the enzyme catalyzes the hydrolysis of angiotensin I to angiotensin II that act as strong agent (vasoconstrictor) with the aid of vasodilative action resulted of the degradation of bradykinin [29]. The proteolytic activity of LAB during milk fermentation and/or the action of pure proteinases on milk proteins leaded to produce numerous of peptides with antihypertensive properties $[7,9,17]$. Several peptides have been shown anti-hypertensive action on spontaneously hypertensive rats and on small groups of human volunteers [23,35]. In addition, several ACE inhibitory peptides have been isolated from the enzymatic hydrolysis of fermentation milk with lactic acid bacteria $[1,12,17]$ or chemical synthesis of peptides according to milk protein sequences [2].

The degradation of milk proteins with proteinases from $L$. helveticus produced peptides with ACE-inhibiting activity had a significant antihypertensive effect in spontaneously hypertensive rats [36]. The same effect was observed with fermented milk containing L. helveticus [37]. Two tripeptides valyl-prolyl-proline (Val-Pro-Pro; VPP) and isoleucyl-prolyl-proline (Ile-Pro-Pro; IPP) were identified as the bioactive peptides which were responsible for this effect [37]. A liquid chromatography-mass spectroscopy (LC-MS) method with Ala-ProPro as an internal standard was used for the quantitative determination of these two peptides in casein hydrolysates [38]. In several short- and long-term human studies where VPP and IPP containing fermented milk products were ingested a blood-pressure lowering effect was observed $[36,39,40]$.

\section{Production of fermented dairy products with ACE in- hibitory peptides}

In dairy products, the production of ACE inhibitory and antihypertensive peptides in situ aroused a lot of interest from scientists since this provides further therapeutic properties to fermented dairy products. During milk fermentation an excessive amount of peptides are liberated from milk proteins as a result of the action of plasmin (indigenous milk enzyme) and proteolytic activity of starter and nonstarter LAB [41,42]. Ferment milk with highly proteolytic species of LAB is widely used to increase the amount of bioactive peptides in fermented dairy products. Thus, selecting the right strains or mixture of strains with highly proteolytic activity and lysis tendency is big challenge to in this approach. Bacterial species ought to not be excessively proteolytic to spoil the product by other peptides such as bitter peptides but yet to provide a high proteolysis of bioactive peptides such as ACE-inhibitory peptides. Since the concentration of ACE-inhibitory peptides appears to rely on a balance between their formation and degradation into inactive peptides and amino acids subject to storage periods and conditions [41,42].

Manipulation of bacterial fermentation of milk play crucial role in increasing anti- ACE-I activity. The enhance anti-ACE-1 activities associated with herbal extracts or type of milk used in fermented milk has been studied [43-45]. This may imply unique properties of herbal extracts and milk interactions towards preferential formation of bioactive peptides, some of which may be have ACE-inhibitory activity. In addition, fish collagen has showed significant effect on increased anti-ACE-1 activities [46,47]. Further studies are needed to isolate and identify the bioactive peptide with anti-ACE-1 activities from fermented milk in the presence of stimulate bacterial growth materials such as medicinal plant and fish collagen.

\section{References}

1. Nejati F, Rizzello CG, Di CagnoR, Sheikh-Zeinoddin M, Diviccaro A, et al. (2013) Manufacture of a functional fermented milk enriched of Angiotensin-I Converting Enzyme (ACE)-inhibitory peptides and ?-amino butyric acid (GABA). LWT - Food Sci Technol 51: 183-189.

2. Miller GD, Jarvis JK, McBean LD (2007) Dairy foods and hypertension. In Handbook of Dairy Foods and Nutrition ( ${ }^{\text {rd }}$ Edn.), CRC Press: Florida: 99-139.

3. Guang C, Phillips RD (2009) Plant food-derived Angiotensin I converting enzyme inhibitory peptides. J Agric Food Chem 57: 5113-5120. [Crossref]

4. Miguel M, Aleixandre MA, Ramos M, Lopez-Fandino R (2006) Effect of simulated gastrointestinal digestion on the antihypertensive properties of ACE-inhibitory peptides derived from ovalbumin. J Agri Food Chem 54: 726-731. [Crossref]

5. Quirós A, Dávalos A, Lasunción MA, Ramos M, Recio I (2008) Bioavalilability of the antihypertensive peptide LHLPLP: transepithelial flux of HLPLP. Int Dairy J 18: 279.

6. Pescuma M, Hébert EM, Rabesona H, Drouet M, Choiset Y, et al. (2011) Proteolytic action of Lactobacillus delbrueckii subsp. bulgaricus CRL 656 reduces antigenic response to bovine $\hat{I}^{2}$-lactoglobulin. Food Chem 127: 487-492. [Crossref]

7. Hernandez-Ledesma B, Amigo L, Ramos M, Recio I (2004) Angiotensin converting enzyme inhibitory activity in commercial fermented products. Formation of peptides under simulated gastrointestinal digestion. J Agri Food Chem, 52: 1504. [Crossref]

8. Ij?s H, Collin M, Finckenberg P, Pihlanto-Lepp?1? A, Korhonen H, Korpela R, et al (2004) Antihypertensive opioid-like milk peptide alactorphin: Lack of effect on behavioural tests in mice. Int Dairy J 14: 201-205.

9. Tauzin J, Miclo L, Gaillard JL (2002) Angiotensin-I-converting enzyme inhibitory peptides from tryptic hydrolysate of bovine alphaS2-casein. FEBS Lett 531: 369-374. [Crossref]

10. Guarner F, Perdigon G, Corthier G, Salminen S, Koletzko B, et al. (2005) Should yoghurt cultures be considered probiotic? Br J Nutr 93: 783-786. [Crossref]

11. Donkor ON, Henriksson A, Vasiljevic T, Shah NP (2005) Probiotic strains asstarter cultures improve angiotensin-converting enzyme inhibitory activity in soyyoghurt. $J$ Food Sci, 70: M375-M381.

12. Papadimitriou CG, Mastrojiannaki AV, Silva AV, Gomes AM, Malcata FX, Alichanidis E (2007) Identification of peptides in traditional and probiotic sheep milk yoghurt with angiotensin I-converting enzyme (ACE)-inhibitory activity. Food Chem 105: 647-656.

13. On, L, Shah NP (2008) Release and identification of angiotensin-converting enzymeinhibitory peptides as influenced by ripening temperatures and probiotic adjuncts in Cheddar cheeses. LWT - Food Sci Technol 4: 1555-1566.

14. Considine T, Healy A, Kelly AL, McSweeney PLH (2000) Proteolytic specificity of elastase on bovine as1-casein. Food Chem 69: 19-26.

15. Salami M, Moosavi-Movahedi AA, Moosavi-Movahedi F, Ehsani MR, Yousefi R, et al. (2011) Biological activity of camel milk casein following enzymatic digestion. $J$ Dairy Res 78: 471-478. [Crossref]

16. Lee K, Lee J, Kim YH, Moon SH, Park YH (2001) Unique properties of four lactobacill in amino acid production and symbiotic mixed culture for lactic acid biosynthesis Curr Microbiol 43: 383-390. [Crossref]

17. Gobbetti M, Stepaniak L, De Angelis M, Corsetti A, Di Cagno R (2002) Laten bioactive peptides in milk proteins: proteolytic activation and significance in dairy processing. Crit Rev Food Sci Nutr 42: 223-239. [Crossref]

18. Robinson RK, Tamime AY, Wszolek M (2002) Microbiology of fermented milks. In R.K. Robinson, (Edr.), Dairy Microbiology Handbook, the Microbiology of Milk and Milk Products, Wiley-Interscience, New York: 367-430.

19. Fox PF, Guinee TP, Cogan TM, McSweeney PLH (2000) Fundamentals of cheese science, Aspen Publishers Inc, Gaithersburg, MD: 384-387.

20. Harte F, Luedecke L, Swanson B, Barbosa-Cánovas GV (2003) Low-fat set yogurt made from milk subjected to combinations of high hydrostatic pressure and thermal processing. J Dairy Sci 86: 1074-1082. [Crossref]

21. Korhonen H (2009) Milk-derived bioactive peptides: From science to applications. $J$ Func Foods 1: 177-187.

22. Korhonen H, Pihlanto A (2006) Bioactive peptides: Production and functionality. Int Dairy J 16: 945-960.

23. Fitzgerald RJ, Murray BA (2006) Bioactive peptide and lactic fermentations. Int $J$ Dairy Technol 59: 118 
24. Shimizu M, Son DO (2007) Food-derived peptides and intestinal functions. Curr Pharm Des 13: 885-895. [Crossref]

25. Kitts DD, Weiler K (2003) Bioactive proteins and peptides from food sources. Applications of bioprocesses used in isolation and recovery. Curr Pharm Des 9: 13091323. [Crossref]

26. Hartmann R, Meisel H (2007) Food-derived peptides with biological activity: from research to food applications. Curr Opin Biotechnol 18: 163-169. [Crossref]

27. Karakurt P, KaÅŸik Ãßi M (2012) Factors affecting medication adherence in patients with hypertension. J Vasc Nurs 30: 118-126. [Crossref]

28. Unger $\mathrm{T}$ (2002) The role of the renin-angiotensin system in the development of cardiovascular disease. Am J Cardiol 89: 3A-9A. [Crossref]

29. Coates D (2003) The angiotensin converting enzyme (ACE). Int J Biochem Cell Biol 35: 769-773. [Crossref]

30. Ramchandran L, Shah NP (2009) Effect of exopolysaccharides on the proteolytic and angiotensin-I converting enzyme-inhibitory activities and textural and rheological properties of low-fat yogurt during refrigerated storage. J Dairy Sci 92: 895-906. [Crossref]

31. Vermeirssen V, Van Camp J, Decroos K, Van Wijmelbeke L, Verstraete W (2003) The impact of fermentation and in vitro digestion on the formation of angiotensinI-converting enzyme inhibitory activity from pea and whey protein. J Dairy Sci 86: 429-438. [Crossref]

32. Kang DG, Kim YC, Sohn EJ, Lee YM, Lee AS, et al. (2003) Hypotensive effect of butein via the inhibition of angiotensin converting enzyme. Biol Pharm Bull 26: 13451347. [Crossref]

33. Fuglsang A, Rattray FP, Nilsson D, Nyborg NC (2003) Lactic acid bacteria: inhibition of angiotensin converting enzyme in vitro and in vivo. Antonie Van Leeuwenhoek 83: 27-34. [Crossref]

34. Vermeirssen V, Van Camp J, Verstraete W (2004) Bioavailability of angiotensin I converting enzyme inhibitory peptides. Br J Nutr 92: 357-366. [Crossref]

35. Vermeirssen V, Camp JV, Verstraete W (2005) Fractionation of angiotensin I converting enzyme inhibitory activity from pea and whey proteins in vitro gasterintestinal digests. J Sci Food Agri 85: 399-405.

36. Tuomilehto J, Lindström J, Hyyrynen J, Korpela R, Karhunen ML, et al. (2004) Effect of ingesting sour milk fermented using Lactobacillus helveticus bacteria producing tripeptides on blood pressure in subjects with mild hypertension. J Hum Hypertens 18: 795-802. [Crossref]

37. Nakamura Y, Yamamoto N, Sakai K, Okubo A, Yamazaki S, et al. (1995) Purification and characterization of angiotensin I-converting enzyme inhibitors from sour milk. $J$ Dairy Sci 78: 777-783. [Crossref]

38. Matsuura K, Mizuno S, Nishimura S, Gotou T, Yamamoto N (2005) Quantitative analysis of the antihypertensive peptides Val- Pro-Pro and lle-Pro-Pro in casein hydrolyzate using an Aspergillusoryzae protease: An LC-MS method. Milchwiss Milk Sci Int, 60: 24-27.

39. Seppo L, Jauhiainen T, Poussa T, Korpela R (2003) A fermented milk high in bioactive peptides has a blood pressure-lowering effect in hypertensive subjects. Am J Clin Nutr 77: 326-330. [Crossref]

40. Bütikofer U, Meyer J, Sieber R, Walther B, Wechsler D (2008) Occurrence of the angiotensin-converting enzyme inhibiting tripeptides Val-Pro-Pro and Ile-Pro-Pro in different cheese varieties of Swiss origin. J Dairy Sci 91: 29-38. [Crossref]

41. Ryh?nen EL, Pihlanto-Lepp?1? A, Pahkala E (2001) A new type of ripened; low-fat cheese with bioactive properties. Int Dairy J, 1: 441-447.

42. Gobbetti M, Minervini F, Rizzello CG (2004) Angiotensin-I-converting enzymeinhibitory and microbial-bioactive peptides. Int J Dairy Technol 57: 173-187.

43. Shori AB, Baba AS (2014) The influence of Allium sativum or Cinnamomum verum on cow- and camel- milk yogurts: proteolytic and angiotensin-I converting enzymeinhibitory activities. Adv Mater Res, 832: 639-643. [Crossref]

44. Baba AS, Najarian A, Shori AB, Lit KW, Keng GA (2014) Viability of Lactic Acid Bacteria, Antioxidant Activity and In Vitro Inhibition of Angiotensin-I-Converting Enzyme of Lycium barbarum Yogurt. Arab J Sci Eng 39: 5355-5362.

45. Shori AB, Baba AS (2013) Antioxidant activity and inhibition of key enzymes linked to type-2diabetes and hypertension by Azadirachta indica-yogurt. J Saudi Chem Soc 17: 295-301.

46. Shori AB, Baba AS, Keow JN (2012) Effect of Allium sativum and fish collagen on the proteolytic and angiotensin-I converting enzyme-inhibitory activities in cheese and yogurt. Pak J Biol Sci 15: 1160-1167. [Crossref]

47. Shori AB, Baba AS, Chuah PF (2013) The Effects of Fish Collagen on the Proteolysis of Milk Proteins in Allium sativum- Yogurt. Taiwan Inst Chem Eng 4: 4701-4706.

Copyright: (C2015 Shori AB. This is an open-access article distributed under the terms of the Creative Commons Attribution License, which permits unrestricted use, distribution, and reproduction in any medium, provided the original author and source are credited. 